\title{
THE INFLUENCE OF BARBITURATES ON COUMARIN PLASMA LEVELS AND PROTHROMBIN RESPONSE *
}

\author{
By PETER G. DAYTON, YAVUZ TARCAN, THEODORE CHENKIN AND \\ MURRAY WEINER \\ (From the New' York University Research Service, Goldwater Memorial Hospital, Welfare \\ Island, New York, N. Y.)
}

(Submitted for publication April 25, 1961 ; accepted May 19, 1961)

Wide individual variations in response to drugs is a common clinical problem, and is especially evident with coumarin anticoagulant therapy (1-3). A possible contributing factor to such variations could be the influence of another presumably unrelated drug upon the response to the coumarin anticoagulant. Reports from several laboratories (4-7) indicate that barbiturates can reduce the prothrombin response to coumarin anticoagulants. This report presents initial results of studies designed to determine the manner by which barbiturates alter the response to coumarins in man, guinea pig and dog.

\section{MATERIAL AND METHODS}

Guinea pigs. Diet, method of handling guinea pigs, and blood sample collection have been reported (8). Drugs were administered to guinea pigs intraperitoneally, barbital and acenocoumarin as aqueous solutions of their sodium salts in 0.5 to $1 \mathrm{ml}$, and chlorobutanol in $1.0 \mathrm{ml}$ of peanut oil.

Dogs. Dogs were maintained on Kibbled dog food (Big Red Co.). They were given biscoumacetate (75 $\mathrm{mg}$ per $\mathrm{kg}$ ) intravenously and barbital orally $(50 \mathrm{mg}$ per $\mathrm{kg}$ ).

Human subjects. Ambulatory, hospitalized subjects free from known liver, kidney or gastrointestinal disease, on a regular hospital diet were studied. Their age ranged from 40 to 60 years. Heptabarbital and acenocoumarin were administered orally. Dicumarol (bishydroxycoumarin) and biscoumacetate were administered either orally or intravenously.

Chemical methods. The procedures for the estimation of prothrombin time (9), Dicumarol (10), and biscoumacetate (11) have been described. Acenocoumarin was determined by the method used for biscoumacetate except that the final extraction was made into a smaller volume $(2 \mathrm{ml})$ of $\mathrm{NaOH}$, and optical density was meas-

\footnotetext{
* Presented in part before the American Heart Association, Philadelphia, $\mathrm{Pa}$., October 25, 1959. This investigation was supported in part by Research Grant H-4347 (C 1), National Heart Institute, United States Public Health Service, Bethesda, Md., and the National Vitamin Foundation, New York, N. Y.
}

ured at $302 \mathrm{~m} \mu$. Barbital and heptabarbital did not interfere with the analyses of Dicumarol, biscoumacetate and acenocoumarin.

\section{RESULTS}

Studies with guinea pigs. Administration of several daily doses of $140 \mathrm{mg}$ per $\mathrm{kg}$ of sodium barbital to guinea pigs had no effect on prothrombin time (Table I). Administration of acenocoumarin produced the expected hypo-prothrombinemia observed previously (8). However, in animals which had received acenocoumarin after pretreatment with barbital, no appreciable hypoprothrombinemia was noted. At this dosage level of barbital the effect was consistent; with lower doses (100 mg per $\mathrm{kg}$ ) block of acenocoumarin effect was less complete. Pretreatment with three daily doses of chlorobutanol (125 $\mathrm{mg}$ per $\mathrm{kg}$ ) also antagonized the hypo-prothrombinemia induced by acenocoumarin. The average prothrombin time in the acenocoumarin-treated control group was 70 seconds (whole plasma) and 53 seconds in the chlorobutanol- and acenocoumarin-treated group. The corresponding time was 145 seconds and 84

TABLE I

Prothrombin response of guinea pigs to acenocoumarin, barbital, and acenocoumarin and barbital

\begin{tabular}{|c|c|c|c|c|}
\hline & \multicolumn{4}{|c|}{ Plasma prothrombin time* } \\
\hline & \multicolumn{2}{|c|}{ Whole } & \multicolumn{2}{|c|}{ Saline diluted $(12.5 \%)$} \\
\hline & Average & Range & Average & Range \\
\hline & \multicolumn{2}{|c|}{ sec } & \multicolumn{2}{|c|}{$\sec$} \\
\hline Saline $(1 \mathrm{ml})$ & 38 & $32-45$ & 54 & $44-67$ \\
\hline Barbitalf & 38 & $32-43$ & 62 & $55-70$ \\
\hline Acenocoumarinf & 138 & $60-250$ & $>200$ & $97-420+$ \\
\hline $\begin{array}{l}\text { Acenocoumarinf } \\
\text { and } \\
\text { barbital } \dagger\end{array}$ & 41 & $33-61$ & 80 & $55-128$ \\
\hline
\end{tabular}

* Blood collected on Day 5 ; nine animals in each group. † Sodium barbital, $140 \mathrm{mg} / \mathrm{kg}$, i.p. daily on Days $1-4$. $\ddagger$ Sodium acenocoumarin, $4.5 \mathrm{mg}$, i.p. on Days 3 and 4 in $1 \mathrm{ml}$ water. 
TABLE II

Effect of pretreatment with barbital on plasma levels of acenocoumarin in guinea pigs *

\begin{tabular}{|c|c|c|c|c|c|c|}
\hline \multirow[b]{3}{*}{ Time } & \multicolumn{3}{|c|}{ No pretreatment } & \multicolumn{3}{|c|}{ Pretreated $\dagger$} \\
\hline & \multirow{2}{*}{$\begin{array}{l}\text { No. of } \\
\text { animals }\end{array}$} & \multicolumn{2}{|c|}{ Plasma level } & \multirow{2}{*}{$\begin{array}{c}\text { No. of } \\
\text { animals }\end{array}$} & \multicolumn{2}{|c|}{ Plasma level } \\
\hline & & Mean & Range & & $\overline{\text { Mean }}$ & Range \\
\hline hrs & \multicolumn{4}{|c|}{$m g / L$} & \multicolumn{2}{|c|}{$m g / L$} \\
\hline $\begin{array}{l}0.5 \\
1\end{array}$ & 5 & & & $\begin{array}{l}8 \\
7\end{array}$ & $\begin{array}{l}26 \\
16\end{array}$ & $\begin{array}{r}18-42 \\
7-24\end{array}$ \\
\hline 1.5 & 11 & 34 & $16-51$ & 9 & 6.6 & $2-12$ \\
\hline
\end{tabular}

* All animals were injected i.p. with $33 \mathrm{mg} / \mathrm{kg}$ of sodium acenocoumarin, and sacrificed at the indicated time.

$\dagger$ Injected with single daily i.p. doses of $140 \mathrm{mg} / \mathrm{kg}$ of sodium barbital beginning 4 days prior to the experiment.

seconds for diluted plasma. Chlorobutanol by itself had no effect on prothrombin time.

Barbital has a half-life in plasma of about 3 days in guinea pigs, and is not appreciably metabolized (12). The half-life of acenocoumarin, as measured by the fall in plasma concentration in guinea pigs, is much shorter than that of barbital. Considerably lower levels of acenocoumarin were found in barbital-pretreated animals than in control animals (Table II). In both groups of animals detectable amounts of acenocoumarin were absent in the plasma at the time of prothrombin estimation (24 hours after dosage).

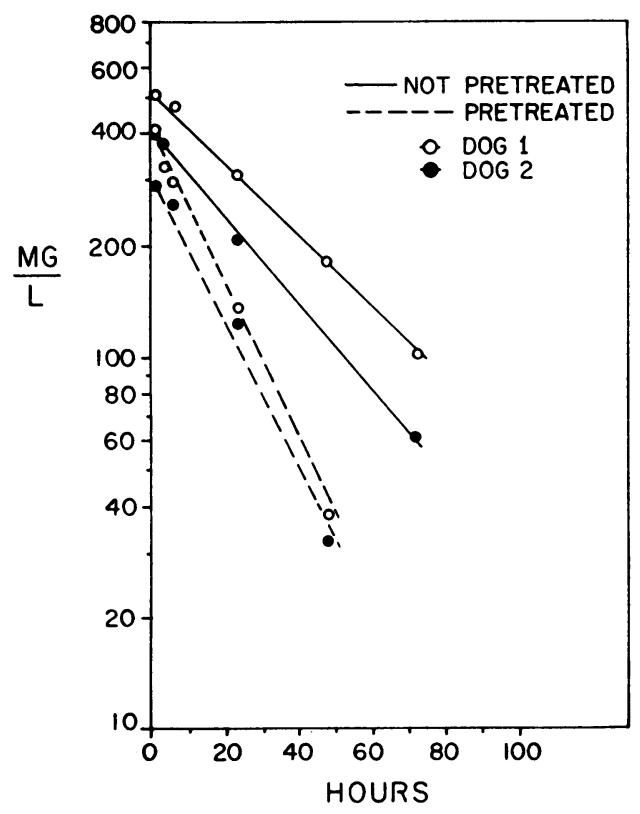

Fig. 1. Plasma levels in two dogs following an intravenous Dose ( $75 \mathrm{Mg} / \mathrm{Kg}$ ) OF Biscoumacetate. The same dose was repeated in the same animal several weeks later, 2 hours after an oral dose of barbital (50 $\mathrm{mg} / \mathrm{kg}$ ).
Studies in dogs. Plasma levels of biscoumacetate after a single intravenous dose of the drug were compared with levels resulting from the same dose after pretreatment of the same animals with barbital (Figure 1). Pretreatment accelerated the decline of the plasma biscoumacetate level and reduced the hypo-prothrombinemic response. Diluted (12.5 per cent) plasma prothrombin time 48 hours after dosage was 75 seconds (Dog 1) and 66 seconds (Dog 2) without pretreatment, and 65 and 48 seconds with pretreatment.

Studies in man. The prothrombin response was measured in the same human subjects after: 1) an oral dose of a coumarin anticoagulant only;

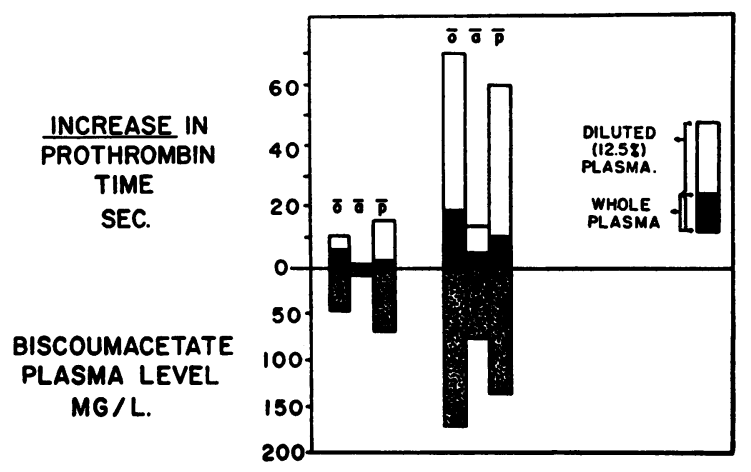

Fig. 2. Maximal prothrombin Response (UPPER BARS) AND BISCOUMACETATE PLASMA LEVEL 5 HOURS AFTER A SINGLE ORAL DOSE OF THE DRUG (LOWER BARS) IN TWO illustrative human subjects. The first set of bars presents values obtained in a relatively resistant subject (Wi), and the second set in a sensitive subject (M). The first bar in each set $(\overline{0})$, results without barbiturate; the center bar (a)), pretreated with $400 \mathrm{mg}$ heptabarbital 1 hour before the anticoagulant; the last bar $(\overline{\mathrm{p}})$, heptabarbital 5 hours after the anticoagulant.

2) pretreatment with an orally administered barbiturate (heptabarbital) followed by an orally administered coumarin; 3) an orally administered coumarin, followed by an orally administered barbiturate; 4) an intravenous dose of a coumarin only ; 5) pretreatment with an orally administered barbiturate followed by an intravenously administered coumarin. Experiments on individual subjects were carried out at 2- to 3 -week intervals.

Results of experiments with biscoumacetate are shown in Figure 2 and Table III ; with Dicumarol in Table IV and with acenocoumarin in Table V. Pretreatment with heptabarbital, followed by an oral dose of any of the three coumarin anticoagulants resulted in lower plasma levels of the cou- 
INFLUENCE OF BARBITURATES ON COUMARINS

TABLE III

Effect of heptabarbital on biscoumacetate plasma levels and prothrombin response in man

\begin{tabular}{|c|c|c|c|c|c|c|c|c|c|c|}
\hline \multirow[b]{3}{*}{ Subject } & \multicolumn{4}{|c|}{ Drugs administered } & \multicolumn{2}{|c|}{$\begin{array}{l}\text { Maximum increase in } \\
\text { prothrombin time }\end{array}$} & \multicolumn{4}{|c|}{$\begin{array}{c}\text { Plasma level of biscoumacetate } \\
\text { after dose at }\end{array}$} \\
\hline & \multicolumn{2}{|c|}{ Biscoumacetate } & \multicolumn{2}{|c|}{ Heptabarbital (400 mg, oral) } & \multirow{2}{*}{$\begin{array}{l}\text { Whole } \\
\text { plasma }\end{array}$} & \multirow{2}{*}{$\begin{array}{r}12.5 \% \text { Saline } \\
\text { diluted plasma }\end{array}$} & \multirow[b]{2}{*}{$1 \mathrm{hr}$} & \multirow[b]{2}{*}{$4 \mathrm{hrs}$} & \multirow[b]{2}{*}{$5 \mathrm{hrs}$} & \multirow[b]{2}{*}{$24 \mathrm{hrs}$} \\
\hline & Dose & Route & Pretreatment & Posttreatment & & & & & & \\
\hline & $m g$ & & hrs before & hrs after & & $\sec$ & & $/ L$ & & $m g_{\prime}^{\prime} L$ \\
\hline Wi & $\begin{array}{l}1,800 \\
1,800 \\
1,800\end{array}$ & $\begin{array}{l}\text { Oral } \\
\text { Oral } \\
\text { Oral }\end{array}$ & $\begin{array}{l}0 \\
1 \\
0\end{array}$ & $\begin{array}{l}\mathbf{0} \\
\mathbf{0} \\
\mathbf{5}\end{array}$ & $\begin{array}{l}5.8 \\
1.2 \\
3.0\end{array}$ & $\begin{array}{r}10.2 \\
0.5 \\
15.0\end{array}$ & & & $\begin{array}{l}44 \\
4.8 \\
66\end{array}$ & $\begin{array}{l}<1 \\
<1 \\
4.6\end{array}$ \\
\hline $\mathbf{M}$ & $\begin{array}{l}1,500 \\
1,500 \\
1,500\end{array}$ & $\begin{array}{l}\text { Oral } \\
\text { Oral } \\
\text { Oral }\end{array}$ & $\begin{array}{l}0 \\
1 \\
0\end{array}$ & $\begin{array}{l}\mathbf{0} \\
\mathbf{0} \\
\mathbf{5}\end{array}$ & $\begin{array}{r}16.2 \\
4.5 \\
10.0\end{array}$ & $\begin{array}{l}68.0 \\
13.0 \\
58.0\end{array}$ & & & $\begin{array}{r}170 \\
75 \\
136\end{array}$ & $\begin{array}{l}9.3 \\
4.1 \\
9.4\end{array}$ \\
\hline $\mathrm{S}$ & $\begin{array}{l}1,500 \\
1,500 \\
1,500 \\
1,500\end{array}$ & $\begin{array}{l}\text { Oral } \\
\text { Oral } \\
\text { i.v. } \\
\text { i.v. }\end{array}$ & $\begin{array}{l}0 \\
1 * \\
0 \\
1\end{array}$ & $\begin{array}{l}\mathbf{0} \\
\mathbf{0} \\
\mathbf{0} \\
\mathbf{0}\end{array}$ & $\begin{array}{l}5.5 \\
2.0 \\
2.0 \\
3.0\end{array}$ & $\begin{array}{r}15.0 \\
9.0 \\
22.5 \\
22.0\end{array}$ & $\begin{array}{l}152 \\
180\end{array}$ & $\begin{array}{r}83 \\
110\end{array}$ & $\begin{array}{r}137 \\
63\end{array}$ & $\begin{array}{l}4.0 \\
3.0 \\
24 \\
31\end{array}$ \\
\hline $\mathrm{Wr}$ & $\begin{array}{l}1,500 \\
1,500\end{array}$ & $\begin{array}{l}\text { i.v. } \\
\text { i.v. }\end{array}$ & $\begin{array}{l}\mathbf{0} \\
1 *\end{array}$ & $\begin{array}{l}\mathbf{0} \\
\mathbf{0}\end{array}$ & $\begin{array}{l}4.0 \\
3.5\end{array}$ & $\begin{array}{l}13.5 \\
11.0\end{array}$ & $\begin{array}{l}138 \\
136\end{array}$ & & $\begin{array}{l}51 \\
47\end{array}$ & $\begin{array}{l}24 \\
23\end{array}$ \\
\hline
\end{tabular}

* Besides the heptabarbital dose given 1 hour before the coumarin, $400 \mathrm{mg} /$ day was given for 3 to 5 days before the day of the experiment.

marin and a decreased prothrombin response, compared with experiments in which the coumarin was given alone, either orally or intravenously. Administration of the barbiturate 5 hours after rather than before the coumarin, had a slight effect in some instances, and none in others. Blood levels of acenocoumarol were low (less than 3.5 $\mathrm{mg}$ per L) in all subjects without pretreatment,

TABLE IV

Effect of heptabarbital on Dicumarol plasma levels and prothrombin response in man

\begin{tabular}{|c|c|c|c|c|c|c|c|}
\hline \multirow[b]{3}{*}{ Drugs administered } & \multirow{3}{*}{$\begin{array}{l}\text { Time of } \\
\text { collection }\end{array}$} & \multicolumn{4}{|c|}{ Prothrombin times } & \multirow{2}{*}{\multicolumn{2}{|c|}{$\begin{array}{l}\text { Plasma conc. of } \\
\text { Dicumarol }\end{array}$}} \\
\hline & & \multicolumn{2}{|c|}{ Subject B } & \multicolumn{2}{|c|}{ Subject $\mathrm{C}$} & & \\
\hline & & Whole & Dil. & Whole & Dil. & Subject B & Subject $\mathrm{C}$ \\
\hline & hrs & \multicolumn{2}{|c|}{$\sec$} & \multicolumn{2}{|c|}{$\sec$} & \multicolumn{2}{|c|}{$m g / L$} \\
\hline Dicumarol, 500 mg p.o. & $\begin{array}{c}\text { Control } \\
24 \\
48 \\
72 \\
96\end{array}$ & $\begin{array}{l}13.0 \\
13.0 \\
20.0 \\
19.5\end{array}$ & $\begin{array}{l}29.5 \\
35.0 \\
51.5\end{array}$ & $\begin{array}{l}14.5 \\
15.0 \\
19.5 \\
14.5\end{array}$ & $\begin{array}{l}33.0 \\
51.5 \\
61.5\end{array}$ & $\begin{array}{l}23.1 \\
19.2 \\
17.1 \\
11.8\end{array}$ & $\begin{array}{r}29.2 \\
8.9 \\
5.7 \\
5.0\end{array}$ \\
\hline $\begin{array}{l}\text { Dicumarol, } 500 \mathrm{mg} \text { p.o. } \\
\text { Heptabarbital, } 400 \mathrm{mg} / \mathrm{day} \\
\text { for } 3 \text { days and } 1 \mathrm{hr} \\
\text { before Dicumarol }\end{array}$ & $\begin{array}{c}\text { Control } \\
24 \\
48 \\
72 \\
96\end{array}$ & $\begin{array}{l}14.5 \\
15.5 \\
17.0 \\
16.0 \\
14.0\end{array}$ & $\begin{array}{l}24.5 \\
27.5 \\
29.5 \\
30.5 \\
34.5\end{array}$ & $\begin{array}{l}14.5 \\
15.0 \\
14.0 \\
14.5 \\
13.0\end{array}$ & $\begin{array}{l}23.0 \\
33.5 \\
30.0 \\
27.0 \\
28.5\end{array}$ & $\begin{array}{r}14.5 \\
14.1 \\
6.9\end{array}$ & $\begin{array}{r}1.8 \\
2.2 \\
3.0 \\
<0.9\end{array}$ \\
\hline $\begin{array}{l}\text { Dicumarol, } 500 \mathrm{mg} \text { p.o. } \\
\text { Heptabartital, } 400 \mathrm{mg} \\
5 \text { hours after Dicumarol }\end{array}$ & $\begin{array}{c}\text { Control } \\
5 \\
24 \\
48 \\
72\end{array}$ & $\begin{array}{l}13.5 \\
19.5 \\
24.0 \\
20.5\end{array}$ & $\begin{array}{l}26.0 \\
37.5 \\
48.0 \\
43.5\end{array}$ & $\begin{array}{l}15.5 \\
18.5 \\
18.0 \\
15.0\end{array}$ & $\begin{array}{l}29.5 \\
40.0 \\
44.0 \\
31.5\end{array}$ & $\begin{array}{l}21.4 \\
13.6 \\
12.0 \\
10.0\end{array}$ & $\begin{array}{r}8.9 \\
12.5 \\
8.6 \\
4.4\end{array}$ \\
\hline Dicumarol, 500 mg i.v. & $\begin{array}{c}\text { Control } \\
5 \\
24 \\
48 \\
72 \\
96\end{array}$ & $\begin{array}{l}13.5 \\
17.0 \\
23.0 \\
16.5 \\
17.5\end{array}$ & $\begin{array}{l}32.0 \\
37.5 \\
31.0 \\
33.0\end{array}$ & $\begin{array}{l}13.0 \\
19.5 \\
24.5 \\
16.2 \\
17.0\end{array}$ & $\begin{array}{l}31.5 \\
39.5 \\
52.0 \\
35.0\end{array}$ & $\begin{array}{l}35.0 \\
30.0 \\
24.0 \\
23.0 \\
18.7\end{array}$ & $\begin{array}{l}63.5 \\
31.8 \\
22.6 \\
18.8 \\
11.9\end{array}$ \\
\hline $\begin{array}{l}\text { Dicumarol, } 500 \mathrm{mg} \text { i.v. } \\
\text { Heptabarbital, } 400 \mathrm{mg} / \mathrm{day} \\
\text { for } 3 \text { days and } 1 \mathrm{hr} \text { before } \\
\text { Dicumarol }\end{array}$ & $\begin{array}{c}\text { Control } \\
5 \\
24 \\
48 \\
72 \\
96\end{array}$ & $\begin{array}{l}13.0 \\
17.0 \\
23.0 \\
28.0 \\
15.5\end{array}$ & $\begin{array}{l}22.5 \\
35.0 \\
43.5\end{array}$ & $\begin{array}{l}14.5 \\
19.5 \\
22.5 \\
26.0 \\
20.5\end{array}$ & $\begin{array}{l}23.5 \\
40.0 \\
50.5\end{array}$ & $\begin{array}{l}49.6 \\
17.0 \\
16.0 \\
14.0\end{array}$ & $\begin{array}{r}43.0 \\
\\
19.2 \\
11.8 \\
8.7\end{array}$ \\
\hline
\end{tabular}


TABLE V

Influence of heptabarbital on maximal prothrombin response. to acenocoumarin in 3 human subjects

\begin{tabular}{clcc}
\hline \hline & & \multicolumn{2}{c}{$\begin{array}{c}\text { Peak prothrom- } \\
\text { bin time }\end{array}$} \\
\cline { 3 - 4 } & & $\begin{array}{c}\text { Whole } \\
\text { plasma }\end{array}$ & $\begin{array}{c}\text { Diluted } \\
(12.5 \%) \\
\text { plasma }\end{array}$ \\
\hline & Subject* & \multicolumn{2}{c}{ sec } \\
E & No pretreatment & 27 & 56 \\
F & Pretreated & 22 & 44 \\
& No pretreatment & 22 & 60 \\
H & Pretreated & 19 & 37 \\
& No pretreatment & 30 & 72 \\
& Pretreated & 25 & 45 \\
\hline
\end{tabular}

* Each subject was given a single oral dose of $50 \mathrm{mg}$ of acenocoumarin (no pretreatment). Three weeks later each subject received an oral dose of $400 \mathrm{mg}$ of heptabarbital daily for 4 days. The last dose was followed in $1 \mathrm{hr}$ by a single $50 \mathrm{mg}$ oral dose of acenocoumarin.

and undetectable with pretreatment. There were individual differences in the response to coumarins, but these variations are well known from previous studies $(2,11)$. Pretreatment with a barbiturate had no appreciable effect on plasma levels of the anticoagulant or prothrombin time response to an intravenous dose of biscoumacetate.

It was noted that after an intravenous dose of biscoumacetate the plasma level at 24 hours was 20 to $30 \mathrm{mg}$ per L, whereas after oral dosage the level was less than $10 \mathrm{mg}$ per L (Table III). Since biscoumacetate is rapidly metabolized (about 25 per cent per hour) in man, and absorption is delayed 1 to 2 hours (11), the plasma levels of the drug 4 to 5 hours after oral dosage are consistently higher than those after intravenous administration of the same dose. Yet, the data in Table III show that at 24 hours there are higher levels following intravenous dosage than after oral dosage. The readings obtained by the method of analysis employed may represent, at least in part, a metabolite of biscoumacetate rather than the drug itself. In any event, it is apparent from these data that the metabolic fate of the drug after oral administration differs from that after intravenous administration. It is therefore conceivable that the observed difference in effect of barbiturates on orally versus intravenously administered biscoumacetate in man may be a metabolic effect rather than an effect on absorption. It has previously been shown (13) that the metabolic pathway of biscoumacetate is quite different in various species.

\section{DISCUSSION}

During studies with human subjects, Avellaneda (6) noted that a variety of orally administered barbiturates (including heptabarbital) decreased the hypo-prothrombinemic response to biscoumacetate in about two-thirds of the cases studied. The mechanism of this effect was not explained. In the present study, measurements of plasma levels of the anticoagulants revealed that barbiturateinduced reduction of hypo-prothrombinemic effect was correlated with lower plasma levels of the anticoagulant in man and in other species. The effect was observed not only with biscoumacetate but also with Dicumarol and acenocoumarin. It was shown that the relative timing of dosage and the route of administration of the coumarin derivatives were important. Barbiturate pretreatment had no appreciable influence on plasma levels or hypo-prothrombinemic effect of intravenously administered coumarin anticoagulants in man. Barbiturate administered after the coumarins also had little or no effect.

These findings exclude a vitamin $\mathrm{K}$-like mechanism to explain the barbiturate effect. Unlike barbiturates, vitamin $K_{1}$ is effective even when given hours or days after the coumarin, and the action is independent of the route of administration of the coumarin; furthermore, Vitamin $\mathrm{K}$ does not affect the plasma levels of coumarin anticoagulants (14). Barbiturates themselves do not affect coagulation $(8,15)$. The barbiturates could, however, influence the physiological disposition of the coumarin. The finding that a drug can influence the disposition of another apparently unrelated drug is not unique in man (16) or experimental animals (17).

The question arises whether barbiturates affect the absorption of coumarin anticoagulants. It is known that absorption of Dicumarol is slow and sometimes incomplete (2), possibly because of the low aqueous solubility of the drug at the $\mathrm{pH}$ range of the gastrointestinal tract. However, acenocoumarin forms a sodium salt which is quite soluble at $\mathrm{pH} 7$ (8) and biscoumacetate is rapidly absorbed from the small intestine (11).

Do barbiturates influence the rate of metabolism of the coumarin? Such an explanation may at first be considered unlikely, since in man the effect was not observed when the coumarin was 
given intravenously. However, these findings in man are different from those in the guinea pig and dog. Pretreatment of guinea pigs with barbital (and also with chlorobutanol in adequate closage) completely inhibited the hypo-prothrombinemic action of intraperitoneally administered acenocoumarin. This species difference may be related to several factors. The doses of barbiturate employed in the experiments with human subjects were small compared with those given to the guinea pigs. In the dog, pretreatment with barbiturate results in lower biscoumacetate levels after intravenous administration of the anticoagulant. Species differences in the metabolic pathway of some coumarins have been clearly demonstrated (13). The data in man suggest differences in the metabolic pathways of oral versus intravenous biscoumacetate. It is therefore possible that, in man, barbiturate pretreatment may influence the metabolic fate (other than absorption) of orally administered biscoumacetate, even though there is no detectable effect on the fate of intravenously administered biscoumacetate.

The results obtained in guinea pigs (antagonism of acenocoumarin by barbital and chlorobutanol) and dogs (antagonism of biscoumacetate by barbital) are similar to the earlier observations of Baumann, Field, Overman and Link $(4,5)$ (antagonism of Dicumarol by chlorobutanol, aminopyrine, and so forth) in rats. Several of the drugs that produce this antagonism, including barbiturates, were known to increase the biosynthesis, excretion and tissue levels of L-ascorbic acid in dogs and rats (18). In fact, Link and co-workers studied the effect of the "vitamin C stimulators" on Dicumarol-induced hypo-prothrombinemia, because they had previously observed that L-ascorbic acid can influence and even antagonize coumarin-induced hypo-prothrombinemia $(19,20)$.

Might the coumarins themselves, like the barbiturates, stimulate the enzymes responsible for coumarin metabolism? After prolonged continuous therapy with biscoumacetate, the plasma level pattern upon discontinuation is the same as that following the initial dose (3). Repeated intravenous doses of Dicumarol or biscoumacetate given to the same subject result in similar plasma level curves $(2,13)$. In fact, in the same subject the half-life of a large dose of Dicumarol or biscoumacetate is longer than that of a small dose
$(2,11)$. Thus, at least in man, coumarins do not accelerate their own metabolism in therapeutic dosage.

Coumarin anticoagulant therapy is frequently accompanied by the administration of other drugs. including barbiturates. This may add to various other difficulties $(1-3,11)$ in controlling the hypoprothrombinemic effect of coumarins in the treatment of thromboembolic diseases. It may be necessary in the future to pay more attention to the mutual influence of concomitant therapy on the physiological disposition of the drugs employed.

\section{SUMMARY}

Results obtained in guinea pig. dog and man show that pretreatment with barbiturates may antagonize the hypo-prothrombinemic effect of coumarin anticoagulants. This effect has been correlated with lower plasma levels of the anticoagulant drugs. In man, route and timing of dosage significantly influence this barbiturate effect.

\section{ACKNOWLEDGMENT}

We wish to thank Drs. J. M. Steele, J. J. Burns and B. B. Brodie for valuable suggestions in the preparation of this manuscript, and Mrs. D. Moses, Mr. Gus John and Mrs. Marcellette Snell for technical assistance.

\section{REFERENCES}

1. Goodman, L. S., and Gilman, A. The Pharmacological Basis of Therapeutics, 2nd ed. New York, Macmillan, 1955, p. 1509.

2. Weiner, M., Shapiro, S., Axelrod, J., Cooper, J. R., and Brodie, B. B. The physiological disposition of Dicumarol in man. J. Pharmacol exp. Ther. 1950, 99, 409.

3. Weiner, M., Simson, G., Burns, J. J., Steele, J. M., and Brodie, B. B. The control of prothrombin activity with Tromexan therapy. Amer. J. Med. 1953, 14, 689.

4. Baumann, C. A., Field, J. B., Overman, R. S., and Link, K. P. Studies on the hemorrhagic sweet clover disease, $\mathrm{X}$. Induced vitamin $\mathrm{C}$ excretion in the rat and its effect on the hypoprothrombinemia caused by $3,3^{\prime}$-methylenebis-(4-hydroxycoumarin). J. biol. Chem. 1942, 146, 7.

5. Link, K. P. The anticoagulant from spoiled sweet clover hay. Harvey Lect. 1943-1944, 39, 162.

6. Avellaneda, M. Interferencia de los barbituricos en la accion del Tromexan. Medicina (B. Aires) 1955, $15,109$.

7. Montigel, C. Die gerinnungsverzögernde Wirkung der Cumarine und deren Beeinflussung durch Barbiturate Butazolidin und andere Substanzen in vivo. Trans. 6th Congress of the European Society of 
Haematology, Part 2, Communications. Basel, S. Karger, 1958, p. 5386.

8. Chenkin, T., Dayton, P. G., Weisberg, L. G., and Weiner, M. Effect of starvation, acenocoumarin and vitamin $\mathrm{K}$ on the coagulation pattern of the guinea pig. Exp. Med. Surg. 1959, 17, 219.

9. Shapiro, S., Weiner, M., Luddecke, H. F., Kroc, R. L., and White, E. J. A simply prepared, standardized, and relatively stable thromboplastin extract for estimation of prothrombin time. Amer. Heart J. 1950, 40, 766.

10. Axelrod, J., Cooper, J. R., and Brodie, B. B. Estimation of Dicumarol, 3, 3'-methylenebis (4-hydroxycoumarin) in biological fluids. Proc. Soc. exp. Biol. (N. Y.) 1949, 70, 693.

11. Brodie, B. B., Weiner, M., Burns, J. J., Simson, G., and Yale, E. K. The physiological disposition of ethyl biscoumacetate (Tromexan) in man and a method for its estimation in biological material. J. Pharmacol exp. Ther. 1952, 106, 453.

12. Burns, J. J., Evans, C., and Trousof, N. Stimulatory effect of barbital on urinary excretion of L-ascorbic acid and nonconjugated D-glucuronic acid. J. biol. Chem. 1957, 227, 785.

13. Burns, J. J., Weiner, M., Simson, G., and Brodie, B. B. The biotransformation of ethyl biscoumacetate (Tromexan) in man, rabbit and dog. J. Pharmacol exp. Ther. 1953, 108, 33.
14. Shapiro, S., Weiner, M., and Simson, G. The effect of water-soluble preparations of vitamin $K$ in Dicumarol-induced hypoprothrombinemia. New Engl. J. Med. 1950, 243, 775.

15. Grassi, G., and Ferraro, C. Influence of barbiturate narcotic drugs on the blood clotting system. Acta anaesth. (Padova) 1956, 7, 437.

16. Dayton, P. G., Chen, W., Blaber, P., and Burns, J. J. Pharmacologist 1961, 3, 80.

17. Conney, A. H., Davison, C., Gastel, R., and Burns, J. J. Adaptive increases in drug-metabolizing enzymes induced by phenobarbital and other drugs. J. Pharmacol exp. Ther. 1960, 130, 1.

18. Longenecker, H. E., Fricke, H. H., and King, C. G. The effect of organic compounds upon vitamin C synthesis in the rat. J. biol. Chem. 1940, 135, 497.

19. Sullivan, W. R., Gangstad, E. O., and Link, K. P. Studies on the hemorrhagic sweet clover disease, XII. The effect of $l$-ascorbic acid on the hypoprothrombinemia induced by $3,3^{\prime}$-methylenebis (4hydroxycoumarin) in the guinea pig. J. biol. Chem. 1943, 151, 477.

20. Overman, R. S., Stahmann, M. A., and Link, K. P. Studies on the hemorrhagic sweet clover disease, VIII. Effect of 2-methyl-1,4-naphthoquinone and $l$-ascorbic acid upon action of $3,3^{\prime}$-methylenebis (4hydroxycoumarin) on the prothrombin time of rabbits. J. biol. Chem. 1942, 145, 155.

\section{SPECIAL NOTICE TO SUBSCRIBERS}

Post Offices will no longer forward the Journal when you move.

Please notify The Journal of Clinical Investigation, Business Office, 333 Cedar Street, New Haven 11, Conn., at once when you have a change of address, and do not omit the zone number if there is one. 